\title{
Improving Students’ Achievement In Writing Narrative Text Through Application of Think Talk Write Strategy
}

\author{
Siti Fitri Hasibuan \\ Departement of English Applied Linguistics \\ Universitas Negeri Medan \\ North Sumatera,Indonesia \\ fitrihasibuan92@yahoo.com
}

\author{
I Wy Dirgeyasa \\ Universitas Negeri Medan \\ North Sumatera,Indonesia
}

\section{Sri Minda Murni \\ Universitas Negeri Medan \\ North Sumatera,Indonesia}

\begin{abstract}
This study was aimed to find out the improvement of students achievement in writing narrative text by using think talk write Strategy at AL-HUSNA boarding school. The subject of this study was students of eight grade Madrasah tingkat tsanawiyah Swasta Al-Husna Marindal. It was consisted of 32 Students. The objective of the study was to improve the students achievement in writing Narrative text by using think talk write Strategy. The research of this study was conducted by using think talk write Strategy in Classroom Action Research. The technique of analyzing the data of this research is applied qualitative and quantitative data. The qualitative data were taken from diary notes, interview sheet, observation sheet and documentation. Based on the writing tests, the students score kept improvement in every test, it could be seen from the improvement of students mean score from pre-test, post test of cycle I and post test of cycle II. The improvement can also e proved by the result of observation sheet and diary notes, it showed that the expression of the students. The quantitative data were taken from writing test. In the pre-test the students gotten up 65 there were only 2 of 32 students $(6,25 \%)$. In the post-test of cycle 1, students who got up 65 there were 8 of 32 students $(25 \%)$. It means that there was improvement about $18,75 \%$. In the posttest of cycle II, students who got up 65 there were 29 of 32 students $(90,62 \%)$. The improvement was about $65,62 \%$. The total improvement of the students score pre-test to post test of cycle II was $84,37 \%$. In another words, the students got the better score to the next meeting. Based on the finding, the alternative hypothesis was accepted It means, that strategy think talk write could improve students achievement in writing Narrative text.
\end{abstract}

Keyword : Achievement, Think Talk Write Strategy, Writing Narrative Text

\section{INTRODUCTION}

In Indonesia English is the first foreign language, study from the elementary level to university level. English also intensively used in international communication, in written as well as in spoken communication. In additional,many books of science, technology,arts, and other published materials issues are written in English.

In English language, there are integrated skills to be mastered such as; listening, speaking, reading, and writing. As Braine and Yoruzu ( 1998 ) states that are English language skills are divided into two categories such as respective skills and productive skills. Reading and listening are considered receptive skills whereas speaking and writing are known as productive skills.

As one of the skill in English language, Nunan ( $2003: 88$ ) defines that writing is the process of thinking to invent ideas, thinking about how to express into good writing, and arranging the ideas into statement and paragraph clearly. It indicates that the learners are expected to explore the ideas and make them into good paragraph. Writing is one of the four skills. The students start learning to communicate through written form as they begin to interact with others at school level. The writing skill is more complicated than that of other language skills. Even sometimes a native speaker of the English language may experience complication in a tricky situation. Basically the writing skill requires a well-structured way of the presentation of thoughts in an organized and planned way ( Braine \& Yoruzu, 1998 )

However, learning English is not an easy task for many learners. Communicative skills both oral and written are difficult. Writing is one of the key skills of the English language, and it is of paramount important in achieving academic success. It is an active, productive skill that students need to learn. Such difficulty may be ascribed to many factors. Richards and Renandya (2012) state that difficulty in writing arises from the difficulty in generating and organizing ideas, and translating these ideas into readable texts.

School in Indonesia especially school still applies the school based 2013 curriculum as a reference to teach English. 
The students should have written and spoken ability in communication. The ability to communicate is the ability to understand and produce the spoken and written text realized in the four languags

But in fact, the students who have learned the foreign language for years are not successful $\mathrm{s}$ the goverment expectacion especially in writing skills. Most of them cannot write well. They always make mistakes in writing. It is shown that many students are not very good in writing. There are many students confused to start their writing concept Individually, a student only uses his own ideas without any supporting ideas from the other sources so it makes a static learning process because ideas appear from a student so it will produce a limited concept depends on a student only. A solitude student is difficult to think an idea. It makes writing process really difficult to start especially to get a main idea. If a student is starting to write, it is difficult to expand specific ideas and it will take longer time to finish a writing process.

These phenomena show us that writing is still being the most diffuculskills in language learning. As what Erkan \& Saban (2011) say that writing is considered one of the most difficult and challenging skills to acquire. Such difficulty may be described to many factors. Richards and Renandya (2012) state that difficulty in writing arises from the difficulty in generating and organizing ideas, and translating these ideas into readable texts. In addition, Shumin (2002) in his research found that there is no doubt that writing is the most difficult skill for students master, the difficulty in generating and organizing ideas.

Strategy Think Talk Write (TTW) was introduced by Hunker and Laughlin in Amrin and Yohana (2012) where the learning process through thinking, talking and writing. This strategy begins with students reading to understand the problem, followed by thinking solution (Think), and then learners communicate its completion (Talk) and finally through discussions and negotiations learners write the results of his thinking (Write). Think Talk Write Strategy allows students to work as group consist of $4-5$ person for each group. The steps in TTW Strategy are Think, Talk and Write. In Think Stage, students with their group need to think individually to find the idea about the theme in lesson. Then Talk Stage, after students already get the idea, students discuss with their group to share their idea of the theme. Next is Write Stage, students start to write the text based the information that what they get in Talk Stage.

The researcher would apply think talk write strategy to motivate students in writing, bring their spirit and the students for learning process. Think talk write allows student to improve their achievement in learning by giving them the opportunity to think, be active in learning process, talking to communicate well, brave to suggest their idea, appreciate someone else and training students to write the result of the discussion into text. This model also gives freedom for students because they can share their idea and student feel more comfortable with their friend.

The researcher would apply Think Talk Write Strategy and conduct the research entitled "Improving Students'
Achievement on Writing Narative Text through Think Talk Write Strategy"

\section{LITERATURE RIVIEW}

\section{A. Theoritical Framework}

To support the ideas of this research, some theories and some informations will be included to help the research design the research.

\section{B. Defenition of Writing}

Writing is a skill, and like other skill, it has to be required. Writing is important to convey ideas, giving instructions, share and preserve knowledge and so on. Although writing is very important, in most cases, it is never considered as an important skill.

Writing is not just about using correct spelling, organizing words and ideas and following grammar, it is much more than that. Writing is a medium of human communication that represents language and emotion with signs and symbols. In most languages, writing is a complement to speech or spoken language. Writing is not a language, but a tool used to make languages be read. Within a language system, writing relies on many of the same structures as speech, such as vocabulary, grammar, and semantics, with the added dependency of a system of signs or symbols. The result of writing is called text, and the recipient of text is called a reader. Motivations for writing include publication, storytelling, correspondence, record keeping and diary. Writing has been instrumental in keeping history, maintaining culture, dissemination of knowledge through the media and the formation of legal systems.

According to Mayers ( 2005) states that writing is a way to produce language you do naturally when you speak . writing is speaking to other on paper or on a computer screen. Writing is also an action a process of discovering and organizing our ideas, putting them on a piece of paper and reshaping and revising them.

\section{Students' Achievement In Writing}

The students' achievement in writing is determined by many factors. It can be affected by the process of learning writing itself and the practical of writing. In order to produces a better achievement in writing, both students and teacher shoud be active in the process learning. And it should be considered that the achievement in writing must be measured. Some criterias were used to measure it, namely content, organization, vocabulary language used, and mechanic. The students were categorized as achieved in writing if they are able write in a good content, organization, vocabulary language used, and mechanic.

\section{Think-Talk-Write Strategy}

In writing, "Think-Talk-Write (TTW)" strategy is a cooperative learning mode to make teaching and learning process easier. It is introduced by Huinker and Laughlin. 
Basically, this strategy is sharing ideas among many students in a group before starting to write. In this strategy, students really active in writing process because they will express their own ideas freely.

TTW strategy divides students into several heterogeneous group to make writing process more effective. In cooperative writing including this strategy, will improving students'mastering concepts. To mastering concepts, this strategy needs instruments as a visualization for students to expand their ideas widely. Generally, the instrument such some pictures that can be used to explore students'creativity and sharing each other. Pictures as a visualization help to expanding point of ideas that can be discussed in a group.

\section{E. Advantages of Think-Talk-Write Strategy}

- Cooperative Think-Talk-Write Strategy helps to improve student's right brain because they will express their ideas spontaneously through a picture.

- The learning central is according to the students activities in discussing something so the teacher is not the central point in study process anymore.

- Student's ideas will more expanded by supporting ideas from his groupmates and it will make a faster writing (conditional).

- TTW strategy makes the students learn to thinking concepts, share their ideas, and discussing a wording in a writing task.

- Ideas from the other groups and corrections from the teacher will be an essential thing to make a better writing.

\section{F. Weaknesses Of Think-Talk-Write Strategy}

- This strategy is effective in description and narrative only.

- Sometimes, it needs more time to presenting and correcting.

- Several students are still ifficult to express their ideas, it depends on their group dividing not the strategy.

- The reality is not always the same with the expectations.

\section{METHODOLOGY OF RESEARCH}

\section{A. Research Design}

This research was applied by Classroom Action Research (CAR). According to Arikunto classroom action research is the research to repair the quality in studying practice, so that focus on processing of study in the class. So that a teacher got information well about research was conducted, by doing steps classroom action research, a teacher could find decision problem that happensin the class. And as researcher Classroom Action Research was conducted with teacher conducted first work, namely teaching in class, stay with student.

\section{B. Subject of Research}

The subject of this research is grade ninth $\left(\mathrm{IX}^{2}\right)$ students of MTs.S Al-Husna Marindal Medan which consisted of 32 students.

\section{Procedure of Research}

The procedure of data collection for this research was conducted by implementing two cycle. Each cycle consists of three meetings and every meeting is included into four steps.

\section{Instrument of Collecting Data}

The instruments of this research were:

1. Test

In collecting the data, multiple choice test was used. The students were asked to answer the question of multiple choice test, which related to the lesson that have learned multiple choice test was given in the pre tes, post test cycle 1 and post test cycle 1 and post test cycle 2 . The time which was given to them to finish the test was 30 minutes .

2. Interview

Interview is conversation get information, usually get consisted of two persons or more. Interview was conducted to get information of the students' achievement in reading descriptive text before giving the treatment.

3. Observation

Collecting the data with using participant observation is showing to express the meaning of the haven't is the essentials in qualitative observation. Research observe has a role to observe the object of research such as place of organization, group of people or some activities at school. Observation was used to identify all condition that happen during the teaching and learning process.

4. Documentation

Documentation is anything written that contains information serving as proof. According to Syahrum and Salim in their book, documentation is all of data are collected and interpreted by researcher. And they was also supported by some media such as : photos, diary notes and video which will be related to research focusing.

\section{E. Technique of Analyzing Data}

The technique of analyzing the data of this research was applied by using qualitative and quantitative data. The data was used to describe the situation during teaching learning process. Test, interview result and observation sheet was analyzed. The quantitative data used to analyze the students' scores.

\section{RESEARCH AND DISCUSSION}

The result was indicated that there was an improvement students' ability in writing narative text by think talk write strategy. It supported by the fact of the mean from the score in every meeting increased. The mean of the first cycle was 
$30 \%$. It was very low because the students still had many difficulties in reading report text, and they had challenges to adapt between the new strategy and the old strategy from their real teacher before. From the result above, the first cycle got the mean $63,67 \%$ and the second cycle was $77,33 \%$. It was indicated that the scores and the means in second cycle were better thebefore (first cycle). The percentage of students who got point up to 65 also grew up. In the pre-test, students who got up 65 there were only 2 of 30 students $(6,67 \%)$. In the post-test of cycle 1 , there were 11 of 30 students who got up $>65(36,67 \%)$. It means that there was improvement about $30 \%$. In the post-test of cycle II, there were 28 of 30 students who got up $>65(93,33 \%)$. The improvement was about $56,66 \%$. The total improvement of the students' score pre-test to post test of cycle II was $86,66 \%$.In another words, the students was became better in the first meeting to next meeting by using think talk write strategy.

Think talk write strategy is an efficient way to learn the course material in a cooperative learning style even less to learn the genre of the text. Think talk write strategy more effective, so the purpose of teaching-learning have reached. It made students enjoyable and their ability was higher in learning writing especially in narrative text. The effect for the students in used think talk write strategy was easier in teaching -learning process. The English teacher implement many strategies in teaching reading especially Think talk write strategy in teaching narratiive text.

In fact students stated that think talk write which made them interested in learning writing. They were more enthusiastic to learn narrative text seriously and focus. Mean while researcher was given more attention for students in studying through think talk write strategy than before conducting it. By analyzing, researcher found that strategy was a flexible strategy than could be used at a variety of levels. It was effective for students in learning about writing especially writing narrative text. Students also studied in a group and they could be shared about the material with their group and then to the other group. As the result above, that there was an improvement on the students' achievement in writing narrative text through application think talk write strategy.

\section{CONCLUSION}

Based on the result of the research, it is concluded the following points, they are:

1. The usage of Think talk write Strategy can make the students more interested in writing narrative text. It was supported by the significant of the different result of the pre-test than was lower ( $6.67 \%)$ than post-test I of the first cycle $(36,67 \%)$ and post-test II of the second cycle ( 93.33\%).

2. The implementation of Think talk write strategy in teaching narrative text was effective.

3. Students' ability in reading report text can be improved by applying trading place strategy. The improvement of students' score from the pre- test of cycle I to the post test of cycle II was about $86,66 \%$. Based on the data analysis, it can be concluded that using $t$ strategy significantly to rading place improved the students' ability in reading report text in Eighth Grade at Mts Swasta Al-Husna Marindal Medan.

\section{SUGGESTION}

On this occasion, the researcher would like to give some suggestions to the stakeholders and the other researcher. It can get benefits from this research. The suggestions are as follow:

1. The Principle of MTs.S Al- Husna Marindal to give direction to English teachers about there are some strategies in English teaching that suitable for students. One of them is team game tournament strategy, that contributed on the students' achievement in writing of narrative text.

2. The English teacher, should be implemented strategy in learning about reading so that the students can more actively, enthusiastically and enjoy during teaching learning process. The last, the material can be gotten by the students easier.

3. The students, it is the better to make a pair discussion to share their opinion and it makes the students more active in learning process, so that the students do not get bored, because generally, they just write the explanation from their teachers that wrote on the black board, it is so monotonously.

4. Other researcher, the finding of this research is subject matters which can be developed widely and deeply by adding other variable or to enlarge the samples.

\section{REFERENCES}

[1] Huy, T. 2015. Problems Affecting Learning Writing Skill Of Grade 11 At Thong Linh High School. Asian Journal Of Educational Research, 2, 53-62.

[2] Muslim, M. 2014. Helping EFL Students Improve their Writing. International journal of humanities and sociel science, 2, 105-11.

[3] Okasha, A., \& Hamdi, S. 2014. Using Strategic Writing Technique For Promoting Writing Skills And Attitude. Journal Of Language Teaching And Research, 3, 674-681.

[4] Ayele, A. 2014. The Effect Of Students' Writing Ability their Use Learning Strategies Of Writing And Gender On Their Attitude Towards Receiveng Training In Learning Strategies Of Writing. International Journal Of Researh, 7, 353-375.

[5] Hewit, D. 2008. Understanding Effective Learning.Great Britain. Bell and Bain Ltd.

[6] Johnson, P., A. 2008. Teaching Reading and Writing. USA. Rowman \& Littlefield Publishers,Inc.

[7] Kunandar.2013.Langkah Mudah Penelitian Tindakan Kelas Sebagai Pengembangan Profesi Guru.Jakarta; Rajawali Pers 